\title{
Marinomonas primoryensis sp. nov., a novel psychrophile isolated from coastal sea-ice in the Sea of Japan
}

Correspondence

Lyudmila A. Romanenko piboc@stl.ru

\author{
Lyudmila A. Romanenko, ${ }^{1}$ Masataka Uchino, ${ }^{2}$ Valery V. Mikhailov, ${ }^{1}$ \\ Natalia V. Zhukova ${ }^{3}$ and Tai Uchimura ${ }^{2}$ \\ ${ }^{1}$ Pacific Institute of Bioorganic Chemistry, Far-Eastern Branch, Russian Academy of Sciences, \\ Vladivostok 690022, Prospect 100 Let Vladivostoku 159, Russia \\ ${ }^{2}$ Tokyo University of Agriculture, Department of Applied Biology and Chemistry, Faculty of \\ Applied Bioscience, Laboratory of Food Science and Technology, Sakuragaoka 1-1-1, \\ Setagaya-ku, Tokyo 156-8502, Japan \\ ${ }^{3}$ Institute of Marine Biology, Far-Eastern Branch, Russian Academy of Sciences, Vladivostok \\ 690041, Russia
}

During the study of microbial communities associated with marine environments, two bacterial strains were isolated from a coastal sea-ice sample, obtained from a sea-ice column at a depth of $0.8 \mathrm{~m}$ in Amursky Bay of the Sea of Japan, near Vladivostok, Russia, in March 2001. The isolates were aerobic, Gram-negative, heterotrophic micro-organisms with a respiratory metabolism, and had phenotypic characteristics similar to those of the genus Marinomonas. Phylogenetic analysis on the basis of $16 \mathrm{~S}$ rDNA sequence similarity revealed that the new isolates belonged to a novel species of the genus Marinomonas, for which the name Marinomonas primoryensis sp. nov. is proposed.

Baumann et al. (1972) reported aerobic, Gram-negative, non-fermentative, non-pigmented, polarly flagellated, marine bacteria containing DNA with a $\mathrm{G}+\mathrm{C}$ content of 43-48 $\mathrm{mol} \%$, and identified that they belonged to a novel genus, Alteromonas. This genus originally comprised four species: Alteromonas marinopraesens that was later renamed Alteromonas haloplanktis (Reichelt \& Baumann, 1973),

Published online ahead of print on 28 February 2003 as DOI 10.1099/ ijs.0.02280-0.

The DDBJ/GenBank accession numbers for the $16 \mathrm{~S}$ rDNA sequences of KMM $3633^{\top}$ and KMM 3634 are AB074193 and AB074194, respectively.
Alteromonas macleodii, Alteromonas communis and Alteromonas vaga (Baumann et al., 1972). However, A. communis and $A$. vaga have characteristics that distinguish them from most of the Alteromonas species described: lack of amylase, gelatinase, lipase and chitinase, and utilization of glycerol, lactate, DL- $\beta$-hydroxybutyrate, $m$-hydroxybenzoate and other carbon sources. DNA-rRNA hybridization experiments performed by Van Landschoot \& De Ley (1983) confirmed the heterogeneity of the genus Alteromonas; A. communis and A. vaga were found to form a separate rRNA branch. A novel genus, Marinomonas, was proposed to accommodate $A$. communis and A. vaga (Van Landschoot \& De Ley, 1983). A novel melanogenic bacterium from the Mediterranean Sea, MMB-1, was described by Solano \& Sanchez-Amat (1999) as a novel species of the genus Marinomonas, namely Marinomonas mediterranea.

The strains tested were isolated from a coastal sea-ice sample, as follows. The sea-ice sample was collected in a sterile flask with a small amount of sterile sea water, kept for 2 days at $15^{\circ} \mathrm{C}$, and melted carefully. An aliquot of melting sea-ice was spread onto a plate of Marine 2216 agar (MA; Difco) and incubated for 7 days at $15^{\circ} \mathrm{C}$. The strains were stored at $-80^{\circ} \mathrm{C}$ in liquid nutrient medium supplemented with $30 \%(\mathrm{v} / \mathrm{v})$ glycerol. The strains, 
designated KMM $3633^{\mathrm{T}}$ and KMM 3634, were deposited in the Collection of Marine Microorganisms (KMM), Pacific Institute of Bioorganic Chemistry, Vladivostok, Russia. Strains KMM $3633^{\mathrm{T}}$ and KMM 3634 were routinely grown on MA, Marine Broth (MB; Difco) and Tryptic Soya Agar (TSA; Serva), prepared with natural sea water. $16 \mathrm{~S}$ rRNA gene sequences of strains KMM $3633^{\mathrm{T}}$ and KMM 3634 (1419 and $1449 \mathrm{bp}$, respectively) were determined and compared as described by Shida et al. (1997). Previously published 16S rDNA sequences were obtained from the EMBL/GenBank/DDBJ databases. The DNA G + C content was determined by the methods of Marmur \& Doty (1962) and Owen et al. (1969). DNA-DNA relatedness was measured spectrophotometrically by using the renaturation rate method (De Ley et al., 1970).

Cellular fatty acid analysis was performed as described by Svetashev et al. (1995). Standard phenotypic characterization of the strains was carried out as described by Baumann et al. (1984), Gauthier \& Breittmayer (1992) and Smibert \& Krieg (1994). Cell morphology was examined by transmission electron microscopy of exponential-phase cells grown in MB. The cells were negatively stained with potassium phosphotungstate $(1 \%, \mathrm{w} / \mathrm{v} ; \mathrm{pH} 7 \cdot 0)$. Motility was observed by the hanging drop method. Growth at $4-41{ }^{\circ} \mathrm{C}$ was examined on MA. Sea water requirement and tolerance of $0-20 \% \mathrm{NaCl}$ were determined using nutrient medium prepared with an artificial sea water base, supplemented with appropriate amounts of $\mathrm{NaCl}$. Glucose utilization and acid production from sugars $(1 \%$, w/v) were tested in Leifson's medium (Leifson, 1963). Utilization of various compounds as sole carbon and energy sources was tested in a mineral liquid medium containing $\left(\mathrm{g} \mathrm{l}^{-1}\right)$ : $\mathrm{NH}_{4} \mathrm{Cl}, 1 \cdot 0 ; \mathrm{K}_{2} \mathrm{HPO}_{4}, 0 \cdot 075 ; \mathrm{CaCl}_{2}, 1 \cdot 45 ; \mathrm{NaCl}, 30 \cdot 0$; $\mathrm{MgCl}_{2}, 6 \cdot 15 ; \mathrm{KCl}, 0 \cdot 75 ; \mathrm{FeSO}_{4}, 0 \cdot 028$; supplemented with $0 \cdot 2 \%(\mathrm{w} / \mathrm{v})$ test substrate. Growth was determined spectrophotometrically after 2 days cultivation.

Strains KMM $3633^{\mathrm{T}}$ and KMM 3634 were aerobic, Gramnegative, halophilic, motile by a single polar flagellum, $0 \cdot 4-0 \cdot 6 \mu \mathrm{m}$ wide and $1 \cdot 6-1 \cdot 8 \mu \mathrm{m}$ long. They have positive or weakly positive oxidase activity and weak catalase activity. Strains KMM $3633^{\mathrm{T}}$ and KMM 3634 were psychrophilic and grew at $4-30^{\circ} \mathrm{C}$, but not at $35^{\circ} \mathrm{C}$. Sodium ions were essential for growth. Growth was supported at $1-6 \% \mathrm{NaCl}$. Smooth, transparent, yellowish colonies were formed on MA. Slight diffusion of yellowish pigment into the medium was observed after 2 days incubation. Both strains grew very poorly on the medium containing Ltyrosine as the sole carbon source, and did not produce melanin-like pigments. Phenotypic and biochemical characteristics of the new strains and other Marinomonas species are listed in Table 1. The major cellular fatty acids of $\mathrm{KMM} 3633^{\mathrm{T}}$ and KMM 3634 were (respectively): $\mathrm{C}_{16: 0}$

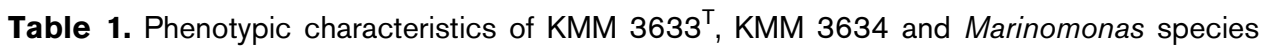

Data from Baumann et al. (1972), Solano et al. (1997), Solano \& Sanchez-Amat (1999) and this study. All strains are positive for motility by a single polar flagellum, $\mathrm{Na}^{+}$requirement for growth and utilization of glycerol, mannitol, citrate, acetate and succinate. All strains are negative for arginine dihydrolase, amylase production, lactose and L-tyrosine utilization. +, Positive; -, negative; W, weak reaction; V, variable reaction between strains; ND, no available data.

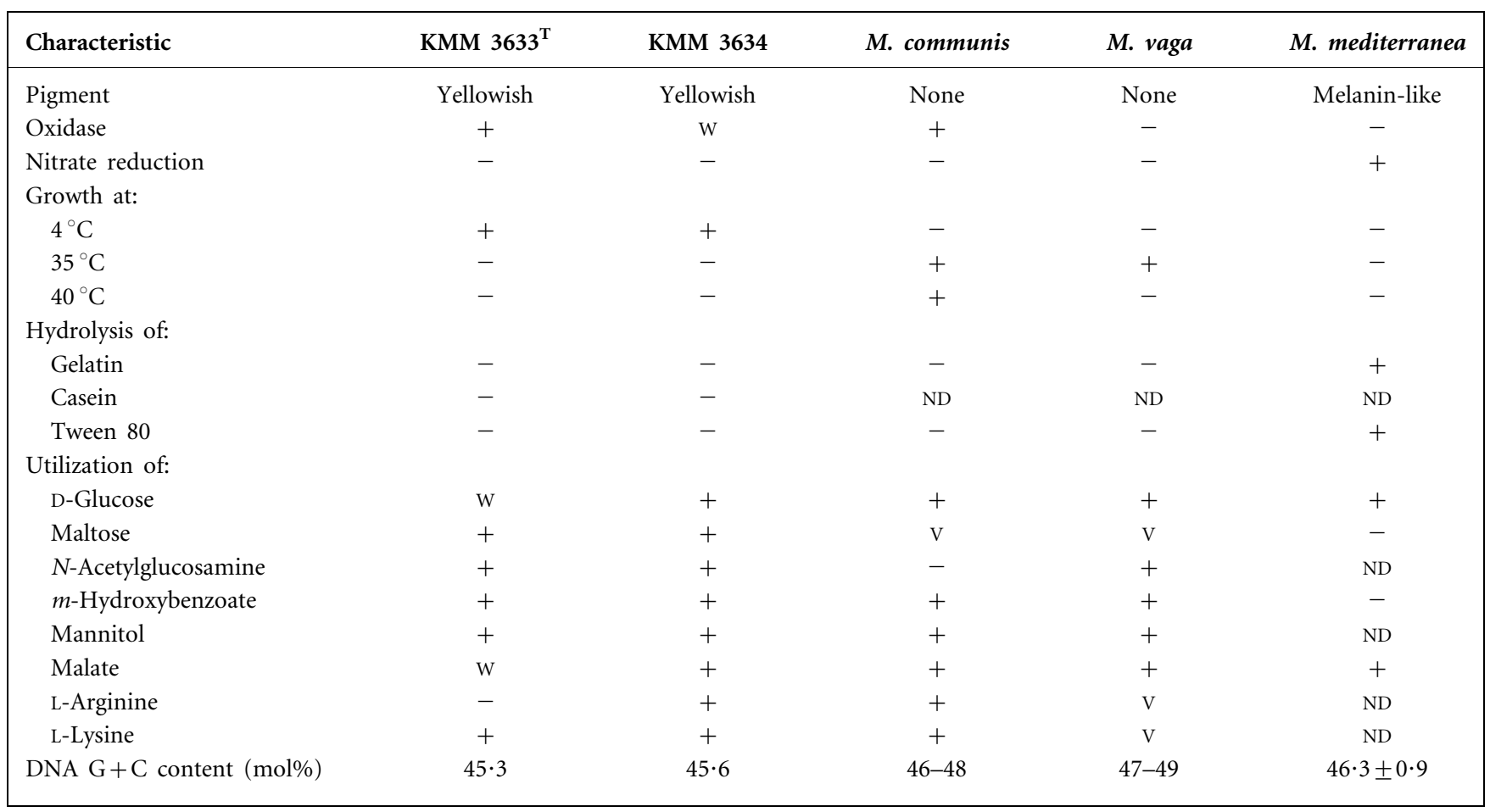




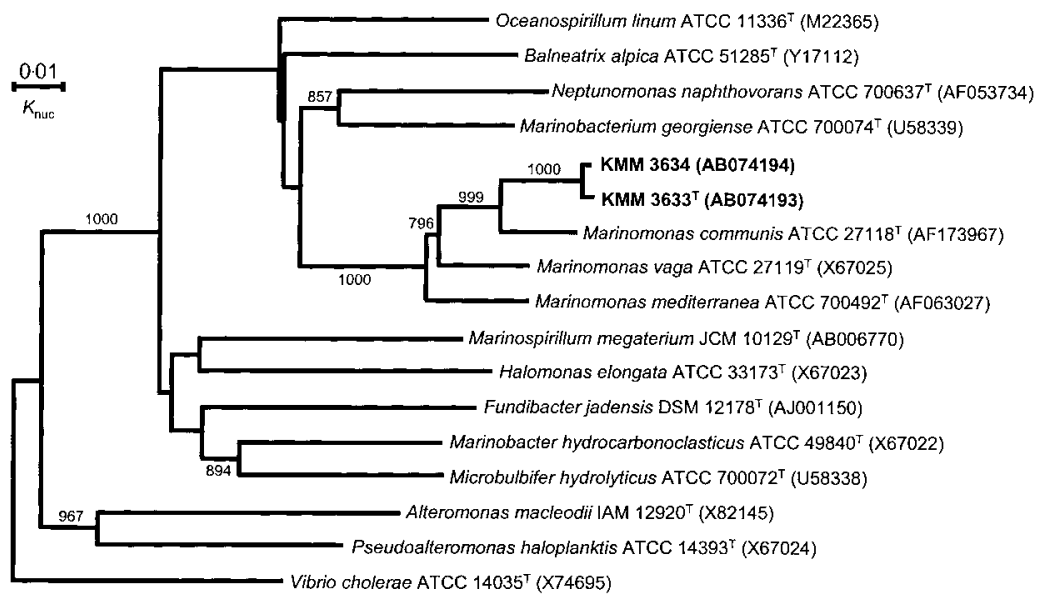

Fig. 1. Phylogenic relationships of $\mathrm{KMM}$ $3633^{\top}, \mathrm{KMM} 3634$ and some related taxa based on $16 \mathrm{~S}$ rRNA gene sequences. The branching pattern was generated by the neighbour-joining method. The significances for particular nodes were obtained by bootstrap analysis (1000 replications). Bar, 0.01 nucleotide substitutions per site.

(24 and $22 \cdot 3 \%), \mathrm{C}_{16: 1} \omega 9 c(27 \cdot 1$ and $30 \cdot 2 \%)$ and $\mathrm{C}_{18: 1} \omega 7 c$ $(35 \cdot 8$ and $35 \cdot 5 \%) . C_{18: 0}(8 \cdot 7$ and $7 \cdot 6 \%)$ and $C_{12: 1}(1 \cdot 9$ and $1 \cdot 7 \%)$ were detected as minor fatty acids. The following fatty acids were at level $<1 \cdot 0 \%$ : $\mathrm{C}_{12: 0}, \mathrm{C}_{14: 0}, \mathrm{C}_{15: 0}$-a, $\mathrm{C}_{17: 0}$ and $\mathrm{C}_{17: 1^{-}}$- .

The DNA G + C content was $45 \cdot 3-45 \cdot 6$ mol\%. DNA-DNA reassociation was $92 \%$ between $\mathrm{KMM} 3633^{\mathrm{T}}$ and $\mathrm{KMM}$ 3634, indicating that the new strains represent the same species (Wayne et al., 1987).

Strains KMM $3633^{\mathrm{T}}$ and KMM 3634 were phylogenetically closely related $(99.5 \% 16 \mathrm{~S}$ rDNA sequence similarity), related to Marinomonas communis with $96 \cdot 4 \%$ similarity and to other members of this genus with $94 \cdot 4-94 \cdot 5 \%$ similarity (Fig. 1). The sequence similarity values between KMM $3633^{\mathrm{T}}$ and previously described Marinomonas type strains were all $<97 \%$, the value that is accepted as indicative of the distinction of different species (Stackebrandt \& Goebel, 1994). Based on both sequence dissimilarity values $(>3 \%)$ and placement in the phylogenetic tree, the isolates do not belong to any other described species and represent a novel Marinomonas species. In addition, there are several phenotypic features that allow the clear differentiation of KMM $3633^{\mathrm{T}}$ and KMM 3634 from other Marinomonas species (Table 1).

Strains KMM $3633^{\mathrm{T}}$ and KMM 3634 differed from M. mediterranea by pigments, oxidase reaction, growth at $4-5{ }^{\circ} \mathrm{C}$, inability to produce lipase or gelatinase or reduce nitrate and ability to utilize maltose and $m$-hydroxybenzoate. Differential characteristics between the new strains and the other previously described Marinomonas species, Marinomonas vaga and $M$. communis, were the maximum and minimum growth temperatures, oxidase reaction, pigmentation, utilization of some carbon compounds and lower DNA G + C contents.

Thus, on the basis of the phenotypic, genotypic and phylogenetic characteristics, we propose a novel species, Marinomonas primoryensis sp. nov.

\section{Description of Marinomonas primoryensis sp. nov.}

Marinomonas primoryensis (pri.mo.ry.en'sis. N.L. fem. adj. primoryensis pertaining to Primorye, Far-Eastern region of Russia).

Cells are Gram-negative, strictly aerobic, 0 0-4-0.6 $\mu \mathrm{m}$ wide, $1 \cdot 6-1 \cdot 8 \mu \mathrm{m}$ long and motile by a single polar unsheathed flagellum. Endospores are not formed. Oxidase reaction is positive or weakly positive. Catalase activity is weak. Sodium ions are required for growth; grows in 1-6\% $\mathrm{NaCl}$. Psychrophilic, neutrophilic and chemoorganotrophic. Growth occurs at $4-30{ }^{\circ} \mathrm{C}$ but not at $35^{\circ} \mathrm{C}$. Transparent colonies are formed, which become yellowish after 36-48 h incubation. Pigment diffuses slightly into the agar. Lipase, caseinase, DNase, gelatinase and amylase are not produced. Negative for arginine dihydrolase, nitrate reduction and acid production from carbohydrates. Utilizes D-glucose, maltose, mannitol, glycerol, $N$-acetylglucosamine, L-asparagine, L-lysine, L-methionine, citrate, malate, $m$-hydroxybenzoate, acetate and succinate; does not utilize arabinose, valine or L-glutamic acid. The predominant fatty acids are $\mathrm{C}_{16: 0}$, $\mathrm{C}_{16: 1} \omega 9 c$ and $\mathrm{C}_{18: 1} \omega 7 c$. The DNA $\mathrm{G}+\mathrm{C}$ content is $45 \cdot 3-45 \cdot 6 \mathrm{~mol} \%$.

The type strain is $\mathrm{KMM} 3633^{\mathrm{T}}$ (= JCM $11775^{\mathrm{T}}=\mathrm{NRIC}$ $523^{\mathrm{T}}$ ). Isolated from coastal sea-ice in Amursky Bay of the Sea of Japan.

\section{Acknowledgements}

The authors are grateful to Dr Kazuo Komagata for his help in editing the manuscript. This study was supported by grant no. 02-04-49517 from the Russian Foundation for Basic Research, and by grant no. 03-19 from the Ministry for Industry, Science and Technologies of the Russian Federation.

\section{References}

Baumann, L., Baumann, P., Mandel, M. \& Allen, R. D. (1972). Taxonomy of aerobic marine eubacteria. J Bacteriol 110, 402-429. 
Baumann, P., Gauthier, M. J. \& Baumann, L. (1984). Genus Alteromonas Baumann, Baumann, Mandel and Allen 1972. In Bergey's Manual of Systematic Bacteriology, vol. 1, pp. 343-352. Edited by N. R. Krieg \& J. G. Holt. Baltimore: Williams \& Wilkins.

De Ley, J., Cattoir, H. \& Reynaerts, A. (1970). The quantitative measurement of DNA hybridization from renaturation rates. Eur J Biochem 12, 133-142.

Gauthier, M. J. \& Breittmayer, V. A. (1992). The genera Alteromonas and Marinomonas. In The Prokaryotes: a Handbook on the Biology of Bacteria: Ecophysiology, Isolation, Identification, Applications, vol. 3, pp. 3046-3070. Edited by A. Balows, H. G. Truper, M. Dworkin, W. Harder \& K.-H. Schleifer. Berlin: Springer.

Leifson, E. (1963). Determination of carbohydrate metabolism of marine bacteria. J Bacteriol 85, 1183-1184.

Marmur, J. \& Doty, P. (1962). Determination of the base composition of deoxyribonucleic acid from its thermal denaturation temperature. J Mol Biol 5, 109-118.

Owen, R. J., Hill, L. R. \& Lapage, S. P. (1969). Determination of DNA base compositions from melting profiles in dilute buffers. Biopolymers 7, 503-516.

Reichelt, J. L. \& Baumann, P. (1973). Change of the name Alteromonas marinopraesens (ZoBell and Upham) Baumann et al. to Alteromonas haloplanktis (ZoBell and Upham) comb. nov. and assignment of strain ATCC 23821 (Pseudomonas enalia) and strain c-A1 of De Voe and Oginsky to this species. Int J Syst Bacteriol 23, 438-441.

Shida, O., Takagi, H., Kadowaki, K., Nakamura, L. K. \& Komagata, K. (1997). Transfer of Bacillus alginolyticus, Bacillus chondroitinus, Bacillus curdlanolyticus, Bacillus glucanolyticus, Bacillus kobensis, and
Bacillus thiaminolyticus to the genus Paenibacillus and emended description of the genus Paenibacillus. Int J Syst Bacteriol 47, 289-298.

Smibert, R. M. \& Krieg, N. R. (1994). Phenotypic characterization. In Methods for General and Molecular Bacteriology, pp. 607-655. Edited by P. Gerhardt, R. G. E. Murray, W. A. Wood \& N. R. Krieg. Washington, DC: American Society for Microbiology.

Solano, F., García, E., Pérez de Egea, E. \& Sanchez-Amat, A. (1997). Isolation and characterization of strain MMB-1 (CECT 4803), a novel melanogenic marine bacterium. Appl Environ Microbiol 63, 3499-3506.

Solano, F. \& Sanchez-Amat, A. (1999). Studies on the phylogenetic relationships of melanogenic marine bacteria: proposal of Marinomonas mediterranea sp. nov. Int J Syst Bacteriol 49, 1241-1246.

Stackebrandt, E. \& Goebel, B. M. (1994). Taxonomic note: a place for DNA-DNA reassociation and 16S rRNA sequence analysis in the present species definition in bacteriology. Int J Syst Bacteriol 44, 846-849.

Svetashev, V. I., Vysotskii, M. V., Ivanova, E. P. \& Mikhailov, V. V. (1995). Cellular fatty acids of Alteromonas species. Syst Appl Microbiol 18, 37-43.

Van Landschoot, A. \& De Ley, J. (1983). Intra- and intergeneric similarities of the rRNA cistrons of Alteromonas, Marinomonas (gen. nov.) and some other Gram-negative bacteria. J Gen Microbiol 129, 3057-3074.

Wayne, L. G., Brenner, D. J., Colwell, R. R. \& 9 other authors (1987). International Committee on Systematic Bacteriology. Report of the ad hoc committee on reconciliation of approaches to bacterial systematics. Int J Syst Bacteriol 37, 463-464. 